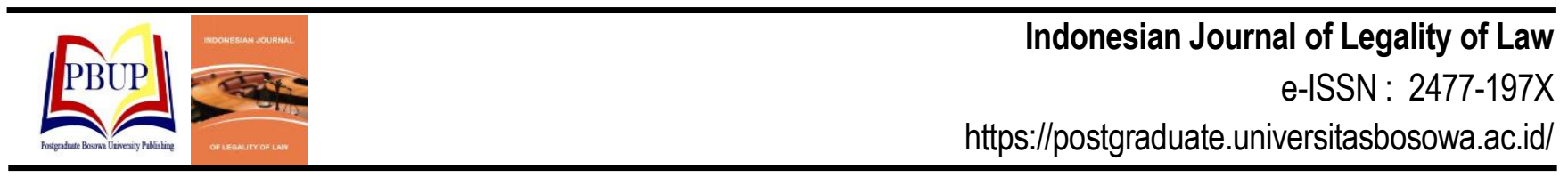

\title{
ANALISIS UPAYA HUKUM KASASI OLEH JAKSA PENUNTUT UMUM TERHADAP PUTUSAN BEBAS
}

\author{
Analysis of Cassation Lawsuits by the Prosecutors towards the Prosecution \\ Munarty $^{1}$, Marwan Mas ${ }^{2}$, Ruslan Renggong ${ }^{2}$ \\ ${ }^{1}$ Magister Ilmu Hukum Program Pascasarjana Universitas Bosowa \\ ${ }^{2}$ Program Studi Ilmu Hukum Program Pascasarjana Universitas Bosowa \\ Email: munartyishak@yahoo.com
}

Diterima: 12 Januari 202`/Disetujui: 01 Juni 2021

\begin{abstract}
ABSTRAK
Secara teori, Jaksa Penuntut Umum (JPU) tidak diperkenankan mengajukan upaya hukum kasasi terhadap vonis bebas sebagaimana diatur dalam Pasal 244 KUHAP. Namun dalam praktek selama ini, Jaksa Penuntut Umum telah beberapa kali mengajukan kasasi terhadap putusan bebas dan beberapa di antaranya di kabulkan oleh Mahkamah Agung. Hal ini terjadi karena larangan mengajukan kasasi atas vonis bebas sebagaimana diatur dalam Pasal 244 KUHAP terkesan multitafsir sehingga menimbulkan perbedaan pendapat dalam penerapannya. Kondisi semacam ini sangat berseberangan dengan prinsipprinsip Negara Hukum, khususnya dalam Upaya mewujudkan kepastian hukum. Atas dasar itulah, Mahkamah Konstitusi melalui putusannya dengan nomor 114/PUU-X/2012 menyatakan bahwa Frasa "kecuali terhadap putusan bebas" sebagaimana tercantum dalam Pasal 244 Undang-Undang Nomor 8 Tahun 1981 tentang Hukum Acara Pidana (KUHAP) adalah bertentangan dengan UUD Negara Republik Indonesia tahun 1945. Menurut pertimbangan hukum Mahkamah Konstitusi, larangan mengajukan kasasi atau Putusan Bebas oleh Jaksa Penuntut Umum tidak memberikan upaya hukum biasa terhadap putusan bebas serta menghilangkan fungsi Mahkamah Agung sebagai Pengadilan Kasasi terhadap Putusan Bebas, sehingga tidak tercapai kepastian hukum yang adil dan prinsip perlakukan yang sama di hadapan hukum.
\end{abstract}

Kata Kunci: Kasasi, Jaksa Penuntut Umum, Putusan Bebas.

\begin{abstract}
In theory, public prosecutors (JPU) are not allowed to file a cassation against the acquittal as stipulated in Article 244 of the Criminal Procedure Code. However, in practice so far, Public Prosecutors have several times filed an appeal against the acquittal decisions and some of them have been granted by the Supreme Court. This occurs because the prohibition on filing an appeal for an acquittal as stipulated in Article 244 of the Criminal Procedure Code has multiple interpretations, which creates different opinions in its application. This kind of condition is very contrary to the principles of rule of law, especially in the effort to create legal certainty. On that basis, the Constitutional Court through its decision number 114 / PUU-X / 2012 stated that the phrase "except for free decisions" as contained in Article 244 of Law Number 8 Year 1981 concerning Criminal Procedure Law (KUHAP) is contrary to the 1945 Constitution of the Republic of Indonesia. According to the legal considerations of the Constitutional Court, the prohibition against filing an appeal or Free Decision by Public Prosecutors does not provide ordinary remedies against free decisions and eliminates the function of the Supreme Court as a Cassation Court against Free Decisions, so that fair legal certainty is not achieved and the principle of equal treatment in the law.
\end{abstract}

Keywords: Cassation, Public Prosecutors, Free Decisions

\section{PENDAHULUAN}

Dalam perkembangannya, KUHAP dianggap belum mampu memenuhi kebutuhan hukum sehingga penegak hukum umumnya banyak melakukan interpretasi hukum terhadap pasal-pasal KUHAP. Di sisi lain, kebutuhan hukum itu juga berakibat terhadap penyimpanganpengimpangan terhadap ketentuan dalam KUHAP untuk memenuhi kebutuhan hukum masyarakat. Salah satu penyimpangan dari KUHAP adalah ketentuan dalam Pasal 244 disebutkan bahwa terhadap putusan perkara pidana yang diberikan pada tingkat terakhir oleh Pengadilan lain selain daripada Mahkamah Agung, terdakwa atau penuntut umum dapat mengajukan permintaan pemeriksaan kasasi kepada Mahkamah Agung kecuali terhadap putusan bebas.

Selanjutnya dalam pasal 67 KUHAP dijelaskan bahwa terdakwa atau penuntut umum berhak untuk minta banding terhadap putusan pengadilan tingkat pertama kecuali terhadap putusan bebas, lepas dari segala tuntutan hukum yang menyangkut masalah kurang tepatnya penerapan hukum dan putusan pengadilan dalam acara cepat. 
Ketentuan Pasal 244 dan Pasal 67 KUHAP pada intinya bahwa putusan pengadilan tingkat pertama dapat dilakukan upaya hukum kecuali putusan bebas (vrijspraak). Akan tetapi ketentuan pasal tersebut telah dilakukakan penyimpangan dengan adanya beberapa yurisprudensi putusan MA yang mengabulkan permohonan kasasi putusan bebas oleh jaksa.

Nudirman menjelaskan ketentuan KUHAP secara tegas melarang pengajuan kasasi terhadap putusan bebas. Dalam praktek, lanjut Nudirman, MA kerap menerima bahkan mengabulkan permohonan kasasi yang diajukan jaksa terhadap putusan bebas. Ia menilai praktek tersebut sebagai wujud tidak independensinya seorang hakim. Menurutnya, hakim hanya mengikuti kehendak jaksa padahal ketentuan UU telah tegas melarang. Lebih lanjut, Moerino menilai yurisprudensi itu bertujuan untuk mengoreksi putusan hakim pengadilan negeri. Bila tak diberikan ruang koreksi melalui kasasi, maka hakim pengadilan negeri dikhawatirkan akan sewenang-wenang dalam membebaskan terdakwa. Ia berpendapat yurisprudensi adalah terobosan hukum yang dilakukan oleh hakim lewat putusannya terhadap sebuah persoalan yang tidak ada aturan hukumnya. Dalam kasus ini, aturan KUHAP secara tegas melarang kasasi terhadap putusan bebas.

Mahkamah Agung mengambil sikap tegas larangan pasal 244 KUHAP atas permohonan kasasi jaksa tentu tidak pula dilakukan secara gegabah, tanpa dasar dan argumen hukum yang jelas. Demikian juga MA dalam merespon pesan Putusan Mahkamah Konstitusi tanggal 28 Maret 2013 No. 114/PUU-X/2012 perlu juga menjadi renungan para hakim agar tidak terlalu gampang menjatuhkan vonis bebas karena telah membatalkan frasa "kecuali terhadap putusan bebas" dalam pasal 244 KUHAP dinyatakan bertentangan dengan UUD 1945." Dengan demikian vonis bebas kini leluasa dikoreksi oleh MA.

Usaha pemerintah untuk menyempurnakan perjalanan operasional KUHAP ditempuh melalui berbagai upaya, seperti ; evaluasi, kebijakan (criminal Policy) dan lain-lain. Upaya-upaya tersebut tampaknya belum mampu memenuhi tuntutan-tuntutan agar pelaksanaan operasionalisasi KUHAP mencerminkan keadilan yang didambakan para pencari keadilan. Bahwa hukum hadir di tengah-tengah masyarakat dijalankan tidak sekedar menurut kata-kata hitam-putih dari peraturan (according to the letter). Melainkan semangat dan makna lebih dalam (to the very meaning) dari undang-undang atau hukum. Adanya perlindungan konstitusional terhadap hak asasi manusia dengan jaminan hukum bagi tuntutan penegakannya melalui proses yang adil.

Bahwa norma dalam pasal 244 UU KUHAP (lembaran Negara Nomor 76 Tahun 1981, tambahan lembaran Negara Nomor 3209) adalah norma yang tidak memiliki kejelasan, ketelitian dan konsistensi dalam proses kepastian hukum dalam perundang-undangan itu sendiri menjadi dasar dari peradilan yang bersih dan bebas dari upaya-upaya konspiratif dan hal ini dapat menimbulkan Constitutional Dictatorship dan bertentangan dengan Pasal 1 ayat (3) UUD 1945 yang secara tegas menyatakan bahwa "Negara Indonesia adalah Negara Hukum"

Bahwa berdasarkan Keputusan Menteri Kehakiman Nomor M.14-PW.07.03 tahun 1983 tentang Tambahan
Pedoman Pelaksanaan KUHAP, jaksa boleh mengajukan kasasi dengan alasan demi hukum, kebenaran, dan keadlian terhadap putusan bebas. Konstitusionalitas Norma hukum Pasal 284 Undang-undang Nomor 8 Tahun 1981 tentang KUHAP tersebut yang pasal 254 yang berbunyi, "Terhadap putusan perkara pidana diberikan pada tingkat oleh pengadilan lain selain daripada Mahkamah Agung, terdakwa atau penuntut umum dapat mengajukan permintaan pemeriksaan kasasi kepada Mahkamah Agung, kecuali terhadap putusan bebas". Ini sudah bertentangan dengan konstitusi, utamanya Pasal 24 ayat (1) dan seterusnya.

\section{METODE}

Tipe penelitian yang digunakan penulis dalam penyusunan penelitian ini adalah Penelitian secara kualitatif. Dalam melaksanakan Penelitian ini Penulis telah memilih Tempat yang menjadi lokasi penelitian adalah Kantor Kejaksaan Negeri Makassar, Pengadilan Negeri Makassar, Teknik pengumpulan data dalam penelitian ini adalah dengan cara Wawancara dan Dokumentasi.

\section{HASIL DAN PEMBAHASAN}

\subsection{Upaya Hukum Kasasi oleh Jaksa Penuntut Umum terhadap Putusan bebas direformulasikan dalam Kitab Undang-Undang Hukum Acara Pidana (KUHAP) yang akan Datang \\ Dalam Kitab Undang-Undang Hukum Acara Pidana} (KUHAP) sebagai payung hukum (umbrella act), dalam Hukum Acara Pidana yang dapat diperankan dalam Sistem Peradilan Pidana Indonesia sudah berjalan sampai saat ini pula secara teoritikal normatif pengaturan akan substansi Putusan Bebas (vrijspraak) dalam Upaya Hukum Kasasi bagi Jaksa Penuntut Umum masih menunjukkan adanya norma yang kabur atau norma yang tidak jelas (unclear norm/geschild van normen). Dengan kata lain apabila dicermati lebih mendalam mengenai keberadaan pengaturan terhadap Putusan Bebas terkait dengan Upaya Hukum kasasi bagi Jaksa Penuntut Umum tersebut, tidak diatur secara pasti dalam Kitab UndangUndang Hukum Acara Pidana (KUHAP) sehingga secara landasan normative yuridikal terjadi kekosongan norma pengaturan (vacuum of norm/lemeeten van normen).

Ketidakjelasan norma hukum yang mengatur Tentang Upaya Hukum Kasasi bagi Jaksa Penuntut Umum terhadap Putusan Bebas tersebut yang terjadi selama ini dalam praktek peradilan Pidana kita disebabkan oleh karena ketentuan Pasal 244 KUHAP secara jelas telah melarang atau tidak memperkenankan Jaksa Penuntut Umum untuk menempuh Upaya hukum kasasi terhadap Putusan Bebas. Seperti telah kita ketahui bahwa berdasarkan Keputusan Menteri Kehakiman Republik Indonesia Nomor : M.14-PW.07.03 Tahun 1983 tanggal 10 Desember 1983 Tentang Tambahan Pedoman Pelaksanaan KUHAP, butir 19 dengan pertimbangan atas dasar situasi dan kondisi demi hukum, keadilan dan kebenaran maka ketentuan Pasal 244 KUHAP diterobos atau disimpangi. Hal ini jelas akan menimbulkan keracuan secara tataran urutan Perundang-Undangan. Norma yang lebih rendah mengeleminasi norma yang lebih tinggi sehingga menimbulkan pula beragam interpretasi dari berbagai kalangan, dalam hal inilah menimbulkan kekaburan norma yang ada dalam KUHAP khususnya tentang pengaturan kasasi terhadap Putusan Bebas tersebut. 
Pembentuk Undang-Undang (pembentuk KUHAP) sebagai pemegang suatu kebijakan legislasi sudah sepatutnya melakukan langkah-langkah hukum, sebagai berikut:

1. Mengadakan revisi terhadap ketentuan Pasal 244 KUHAP, maksudnya bahwa di dalam Kitab UndangUndang Hukum Acara Pidana (KUHAP) yang akan datang perlu dirumuskan secara tegas ketentuanketentuan mengenai Upaya Hukum Kasasi terhadap Putusan Bebas. Yang di dalamnya diantaranya memuat esensi pemberian kesempatan, porsi atau hak kepada Jaksa Penuntut Umum untuk melakukan Upaya Hukum Kasasi terhadap putusan Bebas sehingga adanya kepastian hukum sebagai landasan justifikasi bagi Jaksa Penuntut Umum dalam mengajukan Upaya Hukum Kasasi terhadap Putusan Bebas tersebut dalam rangka memperjuangkan hak-hak pencari keadilan. Dengan adanya perumusan secara tegas dan pasti tentang Hak Jaksa Penuntut Umum terkait Upaya Hukum Kasasi terhadap Putusan Bebas oleh Jaksa Penuntut Umum sehingga ada kepastian hukum yang dapat dijadikan sebagai pedoman dalam penegakan hukum (law enforcement) yang diemban oleh komponen sub system struktur dalam Sistem Peradilan Pidana untuk dapat melaksanakan fungsinya sesuai tuntutan pencari keadilan.

2. Menghapus Keputusan Menteri Kehakiman Republik Indonesia Nomor : M.14-PW.07.03 Tahun 1983 tanggal 10 Desember 1983 Tentang Tambahan Pedoman Pelaksanaan KUHAP, khususnya butir 19 oleh karena dengan adanya Keputusan Menteri Kehakiman ini maka menimbulkan adanya ketentuan norma yang bertentangan antara peraturan yang lebih rendah derajatnya mengenyampingkan ketentuan pasal dalam Undang-Undang. Dengan dihapuskannya Keputusan Menteri Kehakiman tersebut demi kepastian hukum maka hakim tidak perlu lagi melakukan tindakan contra legem terhadap ketentuan Pasal yang ada dalam sebuah Undang-Undang (dalam hubungan ini bahwa hakim melakukan tindakan contra legem terhadap ketentuan Pasal 244 KUHAP) yang menyangkut Upaya Hukum Kasasi oleh Jaksa Penuntut Umum terhadap Putusan Bebas. Tindakan contro legem yang dilakukan hakim selama ini berimplikasi lahirnya yurisprudensiyurisprudensi Mahkamah Agung yang bahkan menambah kerancuan hukum oleh karena menimbulkan beragam interpretasi dari berbagai kalangan terhadap esensi Pasal 244 KUHAP tersebut.

Dengan demikian dapat dipahami bahwa reformasi terhadap KUHAP. Khususnya reformasi terhadap Upaya Hukum Kasasi oleh Jaksa Penuntut Umum atas Putusan Bebas (Pasal 244 KUHAP) adalah merupakan Upaya pembaharuan terhadap substansi hukum acara pidana. Jadi dalam hal ini komponen dari system hukum yang menjadi focus reformasi yaitu komponen substansi

3.2. Dasar Pertimbangan Hakim Pengadilan sehingga Menyatakan Putusan Bebas terhadap Terdakwa dalam Perkara Nomor: 1434/Pid.Sus/2018/PN.Mks.

Dari wawancara dengan Hakim Burhanuddin, menurutnya terdakwa divonis bebas atas beberapa pertimbangan. Majelis hakim membaskan terdakwa karena memiliki pertimbangan bahwa dakwaan Jaksa Penuntut Umum (JPU) tidak terbukti secara sah dan menyakinkan sesuai dengan ketentuan hukum. Katanya saksi tidak ada satupun yang menunjuk arah terdakwa terbukti bersalah sebagaimana dalam dakwaan Jaksa Penuntut Umum, pasalnya para saksi tersebut telah mencabut keterangan dalam berita acara pemeriksaan (BAP) dihadapan Majelis Hakim dimana dalam keterangannya di berita acara pemeriksaan (BAP) Kepolisian. Namun diruangan persidangan keterangan justru dicabut, dan pencabutan laporan itu ditandai dengan surat pernyataan ini ditandatangani di atas materai 6000 di hadapan Majelis Hakim. Sebagaimana yang didakwakan dalam dakwaan pertama,kedua dan ketiga. Dan Jaksa Penuntut Umum diberikan kesempatan kepada hakim untuk memanggil Penyidik untuk dipertemukan dengan para terpidana atas pernyataan di persidangan, namun penyedik itu tidak pernah memenuhi panggilan jaksa karena sudah 3 kali di layangkan surat tapi tidak pernah dipenuhi. Maka pertimbangan itulah Hakim mengambil kesimpulan dan mengganggap terdakwa tidak terbukti bersalah dalam putusan itu juga membebaskan terdakwa dari semua dakwaan dan memerintahkan agar terdakwa segera dikeluarkan dari tahanan. Artinya pembuktian minimum dua alat bukti dan keyakinan hakim sebagaimana Pasal 183 KUHAP itu tidak terpenuhi dan tidak secara sah dengan menyakinkan sesuai dengan ketentuan hukum.

Sehingga dinilai dakwaan Jaksa Penuntut Umum tidak terbukti secara sah dan menyakinkan bersalah melakukan Tindak Pidana sebagaimana ketentuan hukum. Dan hakim memeriksa dakwannya Pasal 114, 112, 131 Undang-Undang Momor 35 Tahun 2009 itu alternatif bentuknya tidak ada perubahan apapun jadi majelis hakim mendakwaa sesuai dakwaan yang ada tidak boleh hakim bertindak diluar dakwaan sehingga majelis hakim membebaskan terdakwa karena memiliki pertimbangan bahwa dakwaan Jaksa Penuntut Umum tidak terbukti secara sah dan menyakinkan sesuai dengan ketentuan hukum.

\section{Putusan Pengadilan Negeri Nomor}

\section{4/Pid.Sus/2018/PN.Mks}

Menimbang, Bahwa dalam perkara ini telash diajukaan barang bukti berupa: barang bukti yang disisikan dari sabu seberat 20.4097 gr yang telah dimusnahkan berdasarkan Berita Acara pemusnahaan teetanggal 22 Februari 2018;

Barang bukti tersebut telah diperhatikan dan dibenarkan oleh saksi yang dikenal sdebagai barang-barang yang berkaitan denagn denagn perkara para saksi yang btelah berkekautan hokum tetap sedangkan terdakwa menyatankan tidak mengetahui.

Menimbang, bahwa selanjutnya telah terjadi telah terjadi haal-hal sebagaimana termuat dalam Berita Acara Persidangan perkara ini, yang untuk mempersingkat uraian Putusab ini harus dianggap telah termuat dan menjadi9 bagaian dari Putusan ini;

Menimbang, bahwa selanjutnya berdasarkan faktk-fakta dan keadaan yang terungkap di persidangan berdasarkan keterangan saksi-saksi, bukti surat dan keterangn terdakwa, maupun adanya barang bukti, maka Majelis Hakim akan memperhitungkan apakah fakta-fakta dan keadaan tersebut dapat memenuhi unsure-unsur dari pasal yang didakwakan kepada terdakwa dan apakah terdakwa dapat bertanggung jawabkan atas perbuatannya;

Minambang, bahwa terdakwa oleh Penuntut Umum telah didakwa dengan didakaan alternatif yaitu melakukan perbuatan sebagaimana diatur dan diancam dalam:

Pertama: Pasal 114 ayat (2) Jo Pasal 132 ayat (1) UndangUndang Nomor 35 Tahun 2009 tentang Narkotika;

Atau: 
Kedua: Pasal 112 ayat (2) Jo Pasal 132 ayat (1)) UndangUndang Nomor 35 Tahun 2009 tentang Narkotika;

Atau:

Ketiga: Pasal 131 Undang-Undang Nomor 35 Tahun 2009 tentang Narkotika;

Menimbang, bahwa selanjutnya Majelis mempertimbangkan tentang

Dakwaan pertama pasal 114 ayat (2) jo Pasal 132 ayat (1) UU RI NO. 35 Tahun 2009 tentang Narkotika yang unsure-unsurnya adalah:

1. Unsur barang siapa;

2. Unsur Tanpa hak dan melawan hokum menawarkan untuk dijual,menjual,membeli,menerima, menjadi perantaraan dalam jual beli, menukar atas menyerahkan Narkotika Golongan Idalam bentuk tanaman;

3. Percobaan atau permufakatan jahat untuk melakukan tindakan pidana Narkotika;

\section{Ad. I Unsur Barang siapa;}

Menimbang, bahwa unsure barang siapa dalam pasal ini adalah barkaitan denagn orang ;

Menimbang, bahwa dalam perkara tersebut para aksi yang merupakan terdakwa dalam hal ini adalah terdakwa. Syamsul RIjal alias Rijal alias KIjang Abd. Hamid yang dihadapkan oleh jaksa Penuntut Umum sebagai terdakwa dalam perkara ini;

Menimbang, bahwa dari fakta-fakta hokum yang terungkap dipersidangan terutaman dari saksi Edi Wilo alias Wilo dan saksi Edi Chandra, SH Bin Mustafa Awing yang merupakan narapidana dalam perkara Narkotika di Pinrang yang perkaranya sudah diputus dsan masing-masing sudah diputus dengan hukumanb 16 tahun ;

Menimbang, bahwa dalam perkara tersebut para aksi yang merupakan terdakwa dalam perkara narkoba tahun 2016 dalam Berita Acara Penyidiknya menerangkan bahwa barang bukti yang didapat yang didapatkan dalam perkara para aksi adalah milik dari terdakwa, adalah bos dari saksi-saksi namun dalam persidangan ini aksi-aksi telah mencabut keterangan dalam BAP tersebut khusus tentang kepemilikan batang bukti bukanlah milik dari terdakwa, tetapi milik dari Puang Salihin yang pada saat itu juga sempat diamankan sersama-sama denagn aksi-aksi dan para aksi juga telah membuat sutar pernyataan dan telah diserahkan dipersidangan.

Menimang, bahwa aksi-aksi menujuk terdakwa sebagai pemilik barang bukti atas perintah dari salihin yang keberadaannya tidak diketahui lagi berada dimana, dan aksiaksi mau dan tega menunjukan terdakwa karena dijanjikan biaya hidup saksi-saksi dan keluarga akan ditanggung oleh Puang Maslihin, tetapi ternyata setelah proses persidangan selesai, maslihin tidak pernah memenuhi janjinya ;

Menimbang, bahwa terlebihdahulu dari itu terungkap bahwa saksi Edi alias Wilo juga tidak pernah kenal dengan terdakwa sebelumnya;

Menimbang, bahwa dari keterangan saksi aa de charger yang menerangkan bahwa terdakwa tidak pernah ada hubungannya dengan shabu-shabu atau nakotika lainnya, karena terdakwa mempunyai pekerjaan tetap/usha tetap yaitu menyediakan material bangunan bila ada yang pesan kemudian dengan truk miliknya sendiri terdakwa atau karyawannya akan mengantarkan material ke pesanan;

Menimbang bahwa dalam keterangannya pula terdakwa tidak mengakui dan tidak mengetahui tentang barang bukti dalam perkara para saksi terdakwa tidak melarikan diri tetapi mengamankan diri karena pada waktu itu suasananya masih panas-panasnya terkait dengan penganganan kasus shabiushabu tersebut, sehingga terdakwa takut karena namanya disebut-sebut dalam perkara tersebut ;

Menimang, bahwa dari fakta dan keadaan tersebut diatas majelis diri dan kemudian atas kemauan sendiri dan keluarga, terdakwa, menyerahkan diri untuk menyelesaikan malash ini, dan selama terdakwa melarikan diri di Tarakan (Kalimantan Utara) terdakwa tinggal dengan teman terdakwa dan membuat usaha sebagai penyediaan material bahan bangunan;

Menimang, bahwa dari fakta dan keadaan tersebut diatas Majelis Hakim menilai bahwa benar terdakwa tidak ada sangkutan pautnya dan tidak terlibat dengan perkara para aksiaksi yang telaah diproses sebelumnya;

Menimbang, bahwa berdasarkan pertimbangan tersebut doatas maka Majelis berkesimpulan bahwa unsure barang siapa dalam pasal ini tidak terbukti oleh sebab itu sudah sepatutnya terdakwa harus bebaskan dari dakwaan pertama tersebut;

Menimbang, bahwa selanjutnya Terdakwa dinyatakan tidak terbukti secara sah dan menyakinkan bermasalah melakukan tindak pidana sebagaimana didakwakan kepadanya, dan oleh karenanya Terdakwa harus dibebaskan dari dakwa tersebut;

Menimbang, bahwa oleh karena terdakwa juga diajukan dengan dakwaan kedua pasal 12 ayat (2) jo pasal 132 ayat (1) UU RI No. 35 Tahun 2009 dan dakwaan ketiga pasal 131 UU RI No.35 / 2009 tentang narkotika dimana dalam dakwaan ketiga pasal tersebuat juga dalam unsure pertamanya adalah sama dengan dakwaan pertama maka dengan demikian terdakwa juga harus dinyatakan tidak terbukti secara sah dan menyakinkan bersalah melaukan tidak pidana sebagaimana didakwaan dalam dakwaan kedua dan ketiga dan oleh karenanya terdakwa harus dinyatakan dibebaskan dari dakwaan kedua dan ketiga tersebut ;

Menimbang, bahwa oleh karena terdakwa dibebaskan dari semua dakwaan, sedangkan dalam perkara ini terdakwa terlah ditahan, maka terdakwa harus segera dikeluarkan dari tahanan, dan kepadanya harus diberikan rehabilitasi;

Menimbang, bahwa oleh karena terdakwa dibebaskan dari semua dakwaan tersebut dia atas, maka mengenai biaya perkara haruslah dibebaskan kepada Negara;

\section{Analisa Putusan}

Majelis hakim menjatuhkan Putusan Bebas Murni terhadap terdakwa berdasarkan Putusan Nomor 1434/Pid.SUS/2018/PN.Mks. menyatakan terdakwa tidak terbukti secarah sah dan meyakinkan bersalah melakukan tindak pidana sebagaimana yang didakwakan dalam dakwaan pertama, kedua, dan dakwaan ketiga membebaskan terdakwa dari dakwaan-dakwaan tersebut, diputusan juga disebutkan agar memulihkan hak terdakwa dalam kemampuan, kedudukan dan harkat serta martabatnya dan membebankan biaya perkara kepada Negara serta memerintahkan agar terdakwa segera dikeluarkan dari tahanan karena tidak memenuhi unsur dua alat bukti yakni keterangan saksi-saksi dan keyakinan hakim.

Saksi-saksi yang dihadirkan oleh Jaksa Penuntut Umum mencabut pernyataan diruangan persidangan. Keterangan dan pencabutan laporan itu ditandai dengan surat pernyataan ini ditandatangani di atas materai 6000 di hadapan Majelis Hakim. Sehingga dinilai dakwaan Jaksa Penuntut Umum 
(JPU) tidak terbukti secara sah dan menyakinkan bersalah melakukan tindak Pidana sebagaimana ketentuan hukum maka majelis Hakim membebaskan terdakwa. Artinya pembuktian minimum dua alat bukti dan keyakinan hakim sebagaimana Pasal 183 KUHAP itu tidak terpenuhi hakim memeriksa dakwaannya Pasal 114, 112, 131, UU Nomor 35 Tahun 2009 itu alternative bentuknya tidak ada perubahan apapun jadi majelis hakim mendakwa sesuai dakwaan yang ada tidak boleh hakim bertindak diluar dakwaan dan wewenang hakim dalam menilai fakta-fakta persidangan hakim akan melihat tidak ada rekayasa dalam persidangan.

Pembuktian memegang peran penting dalam proses pemeriksaan disidang Pengadilan karena pada saat pembuktian inilah nasib terdakwa ditentukan apakah benar bersalah atau tidak bersalah. Maka kesempatan bagi Jaksa Penuntut Umum untuk mengajukan Upaya Hukum Kasasi kepada Mahkamah Agung berdasarkan pasal 183 KUHAP yang menyatakan " Hakim tidak boleh menjatuhkan pidana kepada seorang kecuali apabila dengan sekurang-kurangnya dua alat bukti yang sah ia memperoleh keyakinan bahwa suatu tindak pidana benar-benar terjadi dan bahwa terdakwalah yang bersalah melakukannya" dan pasal 191 Ayat (1) KUHAP yang menyatakan "jika pengadilan berpendapat bahwa dari hasil pemeriksaan disidang, kesalahan terdakwa atas perbuatan yang didakwakan kepadanya tidak terbukti secara sah dan menyakinkan".

Jaksa Penuntut Umum mengajukan permohonan Kasasi ke Mahkamah Agung karena beranggapan bahwa hakim pengadilan Negeri Makassar menjatuhkan Putusan Bebas (vrijspraak) tidak sebagaimana mestinya berdasarkan dengan alasan tersebut Mahkamah Agung mengeluarkan Putusan Bebas Nomor : 1434/Pid.SUS/2018/PN.Mks. argumentasi Jaksa Penuntut Umum menyatakan Putusan Bebas (vrijspraak) sebagai kesalahan dan dijadikan alasan telah sesuai dengan Pasal 183 jo 191 ayat (1) KUHAP.

Sehubungan dengan Putusan bebas yang tidak dapat dimohonkan Upaya Hukum Kasasi oleh Jaksa Penuntut Umum pada Mahkamah Agung seandainya dihadapkan dengan Hak Asasi tiap orang yang memiliki kebebasan secara mutlak dan tidak dapat diganggu kemerdekaannya akan bertentangan dengan isi keadilan distributive yang secara esensial bahwa hakikat keadilan. Bahwa hakikat keadilan distributive adalah keadilan yang dapat diperoleh setiap orang atau semua pihak yang sekaligus pula wujud keadilan hukum bagi semua pihak dan secara asasi diimplementasikan oleh makna Asas Equality Before The law ( asas tiap orang adalah sama dimata hukum).

Asas persamaan di muka hukum bagi setiap orang (equality before the law) yang merupakan salah satu landasan dalam mekanisme KUHAP, tersurat dan tersirat dalam berbagai peraturan Perundang-undangan. Asas persamaan di muka hukum bagi tiap orang dapat ditemukan dalam UndangUndang Dasar Negara Republik Indonesia Tahun 1945. Pasal 28 D ayat (1) bahwa "Setiap orang berhak akan pengakuan, jaminan perlindungan dan kepastian hukum yang adil serta perlakuan hokum yang sama di hadapkan hukum".

Pengaturan lebih lanjut tentang asas equality before the law tersebut yakni dalam Undang-Undang No.8 Tahun 1981 Tentang Kitab Undang-Undang Hukum Acara Pidana (KUHAP), pada Penjelasan Umum, butir 3a KUHAP menyatakan " perlakuan yang sama atas diri setiap orang di muka hukum dengan tidak mengadakan pembedaan perlakuaan".

\section{KESIMPULAN DAN SARAN}

Berdasarkan hasil penelitian dapat disimpulkan bahwa kelemahan-kelemahan dari peraturan Perundang-undangan yang berlaku saat ini (ius constitutum) dalam hal ini yakni Kitab Undang-Undang Hukum Acara Pidana (KUHAP) yang secara lebih spesifik lagi yaitu khususnya mengenai Upaya Hukum Kasasi oleh Jaksa Penuntut Umum terhadap Putusan Bebas (Pasal 244 KUHAP) Pembentuk UndangUndang (pembentuk KUHAP) dalam merumuskan KUHAP yang akan datang khususnya yang mengatur mengenai Upaya Hukum Kasasi terhadap Putusan Bebas (vrijspraak). Bahwa majelis hakim menjatuhkan Putusan Bebas terhadap terdakwa berdasarkan Putusan Nomor:1434/Pid.SUS.PN.Mks karena tidak memenuhi unsur dua alat bukti yakni keterangan saksi-saksi dan keyakinan hakim karena saksi-saksi yang dihadirkan oleh Jaksa Penuntut Umum mecabut pernyataan dan menyebutkan bahwa sebenarnya bukan terdakwa pemilik barang haram tersebut dan bertanda tangan diatas materai 6000 didepan hakim dalam persidangan dan majelis hakim membebaskan terdakwa Jaksa Penuntut Umum (JPU) tidak terbukti secara sah dan menyakinkan sesuai dengan ketentuan hukum sebagaimana dalam pasal 183 KUHAP itu tidak terpenuhi.

\section{DAFTAR PUSTAKA}

A Muhammad Asrun, 2004, Krisis Peradilan Mahkamah Agung di Bawah Soeharto, Cetakan Pertama, Penerbit : ELSAM-Lembaga Studi dan Advokasi Masyarakat, Jakarta.

Abdul Ghofur Anshori. 2006. Filsafat Hukum. Cetakan Pertama. Yogyakarta, Penerbit : Gajah Mada University Press

Achmad Ali, 2009, Menguak Teori Hukum (Legal Theory) Dan Teori Peradilan (Judicial Prudence) Termasuk Interpretasi Undang-Undang (Legisprudence), Edisi Pertama, Cetakan Ke-1, Penerbit : Kencana Prenada Media Group, Jakarta.

Ahmad Kamil,H,M.Fauzan, 2008, Kaedah-kaedah Yurisprudensi, Penerbit: Kencana Prenada Groub, Jakarta

Ahmad M. Romli, 2009, Perkembangan Hukum Dan Penegakan Hak Asasi Manusia Di Indonesia (Dalam Kapita Selekta Hukum), Penerbit : Widya Padjadjaran, Bandung.

Ahmad Mujahidin, 2007, Peradilan Satu Atap Di Indonesia, Cetakan Pertama, Penerbit : PT. Refika Aditama, Bandung.

Allan Coffey, 1994, An Introduction to Criminal Justice System and Process, New York Jersey Prentice, Engelwood Cliff.

Amirudin dan H. Zainal Asikin, 2004, Pengantar Metode Penelitian Hukum, Penerbit : PT.Raja Grafindo Persada, Jakarta.

Ansorie Sabuan, Syarifuddin Pettanase, Ruben Achmad, 1990, Hukum Acara Pidana, Edisi Ke 1, Cetakan Ke-1, Penerbit : Angkasa, Bandung.

Arief Sidharta, B, 2008, Filsafat Hukum Pancasila, Fakultas Hukum Universitas Brawijaya, Malang.

Arifin Rahman, 1998, Sistem Politik Indonesia Dalam Perspektif Struktural Fungsional, Penerbit: SIC, Surabaya. 
Atang Ranoemihardja, R, 1981, Hukum Acara Pidana, Bandung, Penerbit : Tarsito

Bachsan Mustafa, 2003, Sistem Hukum Indonesia Terpadu, Cetakan I, Bandung, Penerbit : PT. Citra Aditya Bakti.

Barda Nawawi Arief (II), 2007, Beberapa Aspek Pengembangan Ilmu Hukum Pidana (menyongsong Generasi Baru Hukum Pidana Indonesia), Semarang, Penerbit : Universitas Diponegoro.

Bazar Harahap, 2007, Hak Azasi Manusia Dan Hukumnya, Edisi Baru, Jakarta, Penerbit : Pecirindo

Darji Darmodiharjo, 2010, Pokok-Pokok Filsafat Hukum, Cetakan Ke-4, Jakarta, PT.Gramedia Pustaka Utama

Demartemen Kehakiman RI, 1982, Pedoman Pelaksanaan KUHAP

Djoko Prakoso, 1985, Kedudukan Justisiabel Di Dalam KUHAP, Cetakan Pertama, Jakarta, Penerbit : Ghalia Indonesia.

Hari Sasangka, 2007, Hukum Pembuktian Dalam Perkara Pidana, Jakarta, Penerbit: PT.Bina Aksara.

Harun M.Husein, 2010, Kasasi Sebagai Upaya Hukum, Cetakan Kedua, Jakarta, Penerbit : Sinar Grafika.

Irda Dahlan, 2007, Upaya Hukum Dalam Perkara, Jakarta, Penerbit : PT. Bina Aksara

Keputusan Menteri Kehakiman Republik Indonesia Nomor: M.14- PW.07.03 Tahun 1983 Tentang Tambahan Pedoman Pelaksanaan KUHAP, Angka 19.

Peraturan Pemerintah Nomor 27 Tahun 1983 Tentang Pedoman Peraturan Pelaksanaan KUHAP

Peraturan Pemerintah Nomor 27 Tahun 1983 Tentang Pedoman Peraturan Pelaksanaan KUHAP

Undang-Undang Nomor 16 Tahun 2004 Tentang Kejaksaan Republik Indonesia.

Undang-Undang Nomor: 8 Tahun 1981 Tentang Kitab Undang-UndangHukum Acara Pidana (KUHAP).

Undang-Undang Dasar Negara Republik Indonesia Tahun 1945. Kitab Undang-Undang Hukum Pidana (KUHP)

Undang-Undang Nomor 3 Tahun 2009 Tentang Perubahan Kedua Atas Undang-Undang Nomor 14 Tahun 1985 Tentang Mahkamah Agung.

Undang-Undang Nomor: 39 Tahun 1999 Tentang Hak Asasi 